\title{
Estimating the burden of smoking: premature mortality, morbidity, and costs
}

\author{
Jonathan M Samet, MD, MS.(I)
}

\begin{abstract}
Samet JM.
Estimating the burden of smoking: premature mortality, morbidity, and costs. Salud Publica Mex 2010;52 suppl 2:S98-SI07.
\end{abstract}

\begin{abstract}
Estimation of the burden of disease attributable to smoking has now become standard in documenting the impact of the tobacco epidemic and in motivating tobacco control.This paper addresses the methods used to estimate the attributable burden of mortality and the related estimation of morbidity and economic costs. Estimates of attributable mortality and morbidity for the Americas range widely, reflecting the maturity of the tobacco epidemic. The estimates are highest for the United States, and lower for Mexico and other countries of the Americas.
\end{abstract}

Keywords: tobacco use; smoking; economic costs; mortality; morbidity; United States; Mexico

\section{Samet JM.}

Estimaciones de la carga debido al consumo de tabaco: mortalidad, morbilidad prematura, $y$ costo. Salud Publica Mex 2010;52 supl 2:S98-SI07.

\section{Resumen}

La medida del impacto de la epidemia de tabaquismo y la promoción del control del tabaco ha sido el estándar para estimar la carga total de enfermedades atribuible al consumo de tabaco. Este artículo estudia los métodos usados para estimar la mortalidad atribuible al consumo de tabaco, así como su morbilidad y los costos económicos. La mortalidad y morbilidad atribuible para la población de los Estados Unidos varía ampliamente, lo que refleja la madurez de la epidemia de tabaquismo. Las estimaciones para los Estados Unidos son altas, y más bajas para México y otros países de América.

Palabras clave: consumo de tabaco; fumar; costos económicos; mortalidad; morbilidad; Estados Unidos; México
$\mathrm{E}$ stimation of the disease burden associated with causal risk factors is now a common practice in translating epidemiological evidence into policy. The general approach was first developed to describe how much lung cancer is caused by cigarette smoking. In 1953, Levin published a landmark paper, "The occurrence of lung cancer in man", that described one still used indicator of disease burden, the population attributable risk. ${ }^{1}$ Levin had carried out one of the five case-control studies of lung cancer reported in 1950 and he carefully tracked the subsequent studies. ${ }^{2}$ In the 1953 paper, he noted that the accumulating evidence "...left little doubt that a definite association exists." He went on to propose three measures of the association of smoking with lung cancer; his third measure is now referred to as the population attributable risk. He described the index as follows: "...the indicated maximum proportion of lung cancer attributable to smoking...based on the assumption that smokers, if they had not become smokers, would have had the same incidence of lung cancer

(I) Department of Preventive Medicine, Keck School of Medicine and Institute for Global Health, University of Southern California. Los Angeles CA, USA.

Accepted on: March 22, 2010

Address reprint requests to: Jonathan M. Samet. University of Southern California, Department of Preventive Medicine.

144| Eastlake Ave., Room 4436. Los Angeles, CA 90089, USA

E-mail: jsamet@usc.edu 
as that found among non-smokers. This assumes that other etiological factors are equal in the two groups..." He then calculated a statistic that he referred to as " $\mathrm{S}$ ", now generally termed the population attributable risk, based on data from four case-control studies. For each study's data, the calculation indicated that the majority of lung cancer cases were attributable to smoking, leading to his finding that: "If the latter figure is correct (note: referring to the highest estimate of $92 \%$ from the studies of Doll and Hill ${ }^{3}$ and Wynder and Graham ${ }^{4}$ ), elimination of smoking would almost eliminate lung cancer."

Estimation of the burden of disease attributable to smoking, and to other causes of disease, has now become standard practice in public health and in translation of research findings into public policy. With regard to smoking, the estimation of disease burden has been used to indicate the urgency of preventive action and the potential magnitude of the burden of disease to be prevented. The general conceptual approach has been expanded to include the economic costs of the morbidity and mortality caused by smoking. The monetization of these costs provides evidence that can be compared to other costs familiar to policy-makers, such as the costs of health care overall or the tax revenues gained from tobacco sales. Estimates of the health costs of smoking have also been used as evidence in litigation against the tobacco industry in the United States, as the basis for recovery of costs spent on treatment of tobacco-caused illness. ${ }^{5}$

This paper provides an overview of the estimation of the burden of tobacco attributable mortality and morbidity with a focus on the Americas. It begins with a review of methodological approaches for estimation of the attributable mortality and morbidity and for estimation of the costs of tobacco-caused morbidity and premature mortality. The paper then reviews some of the estimates of burden and costs that have been made for the Americas, including Mexico. This paper is selective in its coverage of this topic; the 2004 report of the U.S. Surgeon General ${ }^{6}$ and the 2004 report of the Global Bur- den of Disease project ${ }^{7}$ provide comprehensive coverage of attributable risk estimation and Warner et al. address methods for cost estimation. ${ }^{8}$

\section{Estimation of premature mortality and morbidity caused by smoking}

The population attributable risk, as originally proposed by Levin is calculated as:

$$
P A R=\frac{P_{E}(R R-1)}{1+P_{E}(R R-1)}
$$

where $\mathrm{P}_{\mathrm{E}}$ is the prevalence of the exposure and $\mathrm{RR}$ is the relative risk estimated for the risk factor, e.g., smoking. The dependence of PAR on RR and $P_{E}$ is obvious (see Table I). This formula can be extended to incorporate multiple categories of the exposure. For smoking, for example, it could include strata reflecting smoking status (never, current, or former) or other metrics of smoking exposure (amount smoked or duration of smoking). ${ }^{9}$ The example calculations provided in the table demonstrate that a highly prevalent risk factor, even with a relatively weak association, can make a substantial contribution to disease occurrence. Similarly, a factor strongly associated with disease occurrence may make a substantial contribution to disease burden, even if the exposure is relatively uncommon.

While the calculation of PAR, as expressed above, is straightforward, there are substantial subtleties in its interpretation that have been addressed in the epidemiological literature. Greenland and Robbins ${ }^{10}$ and others have considered some of the issues around interpretation of the concept of "attributable". For the diseases that it causes, smoking is not a "necessary" cause in the conceptual model of component causes proposed by Rothman. ${ }^{11}$ Hence, removing smoking, equivalent to reducing $\mathrm{P}_{\mathrm{E}}$ to zero, would not prevent the occurrence of all of the diseases caused by smoking, since lung cancer does occur in never smokers. Because smoking

Table I

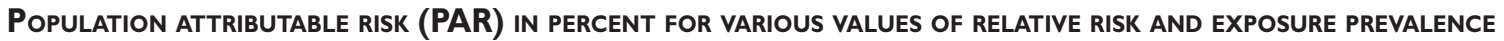

\begin{tabular}{|c|c|c|c|c|c|c|}
\hline & & & & ive Risk & & \\
\hline & & 1.5 & 2.0 & 4.0 & 10.0 & 20.0 \\
\hline & 5 & 2.4 & 4.8 & 13.0 & 31.0 & 48.7 \\
\hline & 25 & II.I & 20.0 & 42.9 & 69.2 & 82.6 \\
\hline evalence or exposure $\left(\mathrm{r}_{\mathrm{E}}\right), \mathrm{o}_{0}$ & 50 & 20.0 & 33.3 & 60.0 & 81.8 & 90.5 \\
\hline & 75 & 27.3 & 42.9 & 69.2 & 87.1 & 93.4 \\
\hline
\end{tabular}


is not a necessary cause, some of the cases of disease in smokers reflect the action of other causal factors. For example, some deaths from coronary heart disease in smokers would have occurred absent smoking. For the purpose of burden calculation, the estimation is directed at those deaths that have occurred in excess because of smoking, but not at all deaths in a particular category of disease for which smoking is a cause.

The formula proposed by Levin has been widely used for calculating smoking-attributable morbidity and mortality. The U.S. Centers for Disease Control and Prevention (CDC) has developed software for its application, Smoking-Attributable Mortality, Morbidity, and Economic Costs (SAMMEC) to facilitate estimation. ${ }^{12}$ In its application to smoking, the PAR is estimated for the various causes of death that are causally associated with smoking. Most often, an estimate of current prevalence, possibly with stratification of ever smokers as current or former, is used to estimate $\mathrm{P}_{\mathrm{E}}$. The RR estimates generally used in the United States and embedded in SAMMEC have come from the cohort study of over one million Americans carried out by the American Cancer Society, generally referred to as Cancer Prevention Study (CPS) II..$^{13}$ This cohort was enrolled in the early 1980s and smoking histories were obtained at that time, but not subsequently for the majority of cohort members. Consequently, the RR estimates used for PAR estimation have come from the first years of follow-up of the cohort to limit misclassification of smoking status as current smokers in the cohort becoming former smokers, paralleling the trend in the US over the same period. The cause-specific PARs are then applied to the numbers of deaths in the corresponding categories of the International Classification of Disease to obtain the numbers of premature deaths attributable to smoking.

For example, the 2004 report of the U.S. Surgeon General reports 11.9 million smoking-attributable deaths in total for the period 1965-1999 based on this method. There is substantial variation in the numbers by causeof-death, reflecting the varying baseline rates of disease and the RR estimates (Table II). Cardiovascular diseases dominate the total because of the much higher absolute rates of cardiovascular disease compared to cancer and chronic obstructive lung disease during this period.

There are several strong assumptions embedded in using the SAMMEC approach for calculating smokingattributable mortality. These include:

- In using current smoking prevalence for $\mathrm{P}_{\mathrm{E}^{\prime}}$ there is an assumption that the burden estimated reflects the current smoking profile rather than past or cumulative smoking of the population of interest.
- In using the RR estimates from CPS II, there is an assumption that these estimates can be extended to the population as a whole for the time period of interest. The population's distribution of amount smoked and duration of smoking might differ from that of CPS II participants.

Peto and colleagues ${ }^{14}$ have proposed an indirect approach that uses the lung cancer mortality rate as an overall population measure of exposure to smoking. Because most lung cancer cases are caused by smoking in most countries, the lung cancer mortality rate is reflective of prior smoking and associated risk for disease. The absolute excess mortality rate for lung cancer is calculated with reference to the never smoker rate in CPS II. Using the lung cancer rate as the reference, the relative impact of smoking is calculated for other diagnostic categories, including upper aerodigestive cancers, other cancers, chronic airways obstruction, other respiratory diseases, and vascular diseases. The comparative impact of smoking on these diseases, compared to lung cancer, provides a smoking impact ratio used for PAR estimation. The most recent calculations based on this method were reported by Peto et al. in 2006. ${ }^{15}$

Beyond the attributable number of premature deaths, the burden of a risk factor is further characterized by the associated morbidity, generally expressed as years of potential life lost (YPLL) and as disability adjusted life years (DALYs). ${ }^{16}$ The YPLL captures the extent to which disease is premature, while the DALY extends the estimation of morbidity to capture the consequences of disease occurrence for healthy life expectancy. Further details on estimation of YPLLs and DALYs are provided in the WHO health statistics and health information systems for the Global Burden of Disease. ${ }^{17}$

\section{Estimation of the health costs of smoking}

Estimation of the health costs of smoking is also grounded in the concept of excess risk. The calculations have the objective of estimating the additional costs of health care incurred because some people smoke within a population. The costs might be extended to include those from lesser work productivity and greater absenteeism from work and from life shortening. The argument has been made that the shorter lifespan of smokers, on average, benefit nonsmokers, since smokers draw less from pension funds or social security systems. This has been cynically referred to as "the death benefit", coming to nonsmokers from smokers, a line of reasoning that was set aside in the litigation in the United States. One 
Table II

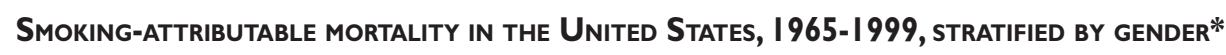
Disease category (ICD-9 code) $)^{\dagger}$
Males
Females
Total

Neoplasms ${ }^{\ddagger}$

\begin{tabular}{|c|c|c|c|}
\hline Lip, oral cavity, pharynx (I40-I49) & 145100 & 36200 & 181300 \\
\hline Esophagus (I50) & 151000 & 38500 & 189500 \\
\hline Stomach (I5I) & 97000 & 14400 & 111300 \\
\hline Pancreas (157) & 116500 & 77100 & 193500 \\
\hline Larynx (16I) & 85000 & 14600 & 99600 \\
\hline Trachea, bronchus, lung (162) & 2286800 & 812200 & 3099000 \\
\hline Cervix uteri $(180)$ & $N A^{\S}$ & 18000 & 18000 \\
\hline Urinary bladder (I88) & 113900 & 29700 & 143600 \\
\hline Kidney, other urinary (I89) & 74700 & 8200 & 82900 \\
\hline Acute myeloid leukemia (205.0) & 21800 & 4800 & 26600 \\
\hline Total & 3091600 & I 053700 & $4 \mid 45400$ \\
\hline
\end{tabular}

Cardiovascular diseases ${ }^{\ddagger}$

Ischemic heart disease (410-414)

\begin{tabular}{|c|c|c|c|}
\hline Aged $35-64$ years & I 302400 & 335700 & 1638100 \\
\hline Aged $\geq 65$ years & I 214800 & 646100 & 1860900 \\
\hline Other heart disease $(390-398,415-4 \mid 7,420-429)$ & 608300 & 253800 & 862100 \\
\hline \multicolumn{4}{|l|}{ Cerebrovascular disease $(430-438)$} \\
\hline Aged $35-64$ years & 170400 & 156100 & 327200 \\
\hline Aged $\geq 65$ years & 175200 & 134200 & 309400 \\
\hline Atherosclerosis (440) & 145800 & 61800 & 207500 \\
\hline Aortic aneurysm (44I) & 203300 & 75100 & 278500 \\
\hline Other arterial disease (442-448) & 33000 & 22300 & 55300 \\
\hline Total & 3853200 & I 685800 & 5539000 \\
\hline
\end{tabular}

Respiratory diseases ${ }^{\ddagger}$

\begin{tabular}{llll}
\hline Pneumonia, influenza (480-487) & 287300 & 127100 & 414400 \\
\hline Bronchitis, emphysema (490-492) & 459000 & 169800 & 628800 \\
\hline Chronic airways obstruction (496) & 694400 & 419000 & 1 II3 400 \\
\hline Total & 1440700 & 715800 & 2 I56 500
\end{tabular}

Perinatal conditions

\begin{tabular}{lrrr}
\hline Short gestation/low birth weight (765) & 16700 & 13300 & 29900 \\
\hline Respiratory distress syndrome (769) & 10800 & 6700 & 17500 \\
\hline Other respiratory conditions in newborns (770) & 20600 & 15400 & 36000 \\
\hline Sudden infant death syndrome (798.0) & 6140 & 4800 & 10900 \\
\hline Total & 54200 & 40200 & 94400 \\
\hline All conditions & 8439700 & 3495500 & 11935200
\end{tabular}

Note: All figures are rounded and hence do not add up.

* Estimates exclude deaths from residential fires caused by smoking and deaths from secondhand smoke exposure.

International Classification of Diseases, 9th Revision.

$\ddagger$ Among persons aged $\geq 35$ years.

$\S N A=$ Not applicable.

Source:Adapted from the 2004 report of the U.S. Surgeon General ${ }^{6}$ 
simulation study from the Netherlands showed that health care costs would be increased for the long run by successful smoking cessation. ${ }^{18}$ Regardless, the tobacco industry profits without contributing to pay the costs of care for the diseases that its products cause.

In the United States, substantial emphasis was given to the health costs of smoking because of litigation directed at recovering expenditures for health care for disease caused by smoking. ${ }^{8}$ During the 1990 s, most states brought lawsuits against the tobacco industry to recover funds expended by the states for treatment of disease caused by smoking. Calculations were also made at the national level for the litigation brought by the U.S. Department of Justice against the tobacco industry. ${ }^{19}$

The target for estimation is the smoking-attributable fraction (SAF) of costs, analogous to the population attributable risk. In considering the health care expenditures attributable to smoking, the total costs for a particular smoker include: those costs for people like the smoker but who do not smoke; the additional, general costs for a smoker; and the additional costs for smokingcaused disease. In total, the latter two cost components constitute the smoking-attributable fraction or the SAF. Ideally, the SAF is estimated from data acquired during tracking of a representative cohort of smokers and nonsmokers with acquisition of information on all health expenditures. In the United States, the National Medical Expenditure Survey was used for this purpose in a number of estimates made for litigation and other purposes by the various states of the United States. ${ }^{20,21}$ This survey, carried out most recently in 1987, collected information on medical expenditures, diseases, and smoking so that the association of smoking with expenditures could be estimated. Zeger et al. ${ }^{22}$ describe the use of this survey to calculate expenditures for the litigation in the State of Minnesota. Subsequently, the Medical Expenditure Panel Survey has been implemented in the United States and its data offer an updated resource for cost estimation. ${ }^{19}$

\section{Estimates of burden and costs for the Americas}

Diverse estimates of the smoking-attributable burden of disease have been reported for the Americas, other than those made by the U.S. CDC for the United States (Table III). The 1992 report of the U.S. Surgeon General, Smoking and Health in the Americas, provided estimates for 1985 for various countries in the Americas, including Mexico. ${ }^{23}$ The methodology conceptually followed the SAMMEC approach, using CPS II RR estimates but with adjustment for the maturity of the smoking epidemic in each individual country based on the country's lung cancer mortality rate. For example, for Mexico, the RRs were scaled by a factor of 0.376 , based on the lung cancer rate for Mexico. Table III provides estimates by sex; the report also provides overall estimates that are adjusted upwards for potential sources of uncounting. Overall, an estimated 526000 deaths were attributed to tobacco use in the Americas of which 14200 were in Mexico and 390200 were in the United States, with the remainder coming from the other countries. The substantially lower estimate for Mexico reflects differences in population size and age structure, the maturity of the epidemic, and smoking prevalence and amount smoked. These estimates for 1985 cannot be considered as applicable to the current situation.

Using the approach of Peto et al., ${ }_{14}$ Ezzati and Lopez $^{24}$ provided estimates for the Americas by WHO subregion (AMR A comprises Canada, Cuba, and the U.S.; AMR $B$ includes Mexico and other middle-income countries; and AMR C includes the low-income countries). The total figure, 873000 , represents an increase of about $75 \%$ from the 1985 estimate, but the methods are different. The overall total is still driven by the United States.

The INTERHEART study provides estimates for myocardial infarction, based on a uniform protocol applied in 52 countries. ${ }^{25}$ The researchers used case-control data to estimate PAR values: $38.3 \%$ for South America and $26.1 \%$ for North America.

Beyond the estimates made for the United States (Table II), estimates have been made for a number of specific countries in the Americas, including Mexico (Table IV). Three sets of estimates of smoking-attributable mortality have been made for Mexico: 1) Those for 1985 included in the 1992 Surgeon General's Report, ${ }^{23}$ 2) for 1992, using SAMMEC and scaling with the lung cancer mortality rate for Mexico; ${ }^{26}$ and 3) for 2004, using the methods of the Global Burden of Disease project. ${ }^{27}$ The estimates cannot be directly compared, given the differing methods and data sets used for estimation. They show that smoking has remained a far weaker cause of mortality in Mexico compared to the United States across the two decade span from 1985 to 2004. The comparative and sub-national analyses reported by Stevens et al. are particularly useful for current planning. Other risk factors-high blood glucose, obesity, high blood pressure, and alcohol-presently contribute more to premature mortality than smoking. This pattern of attributable mortality implies a need to assure that smoking does not increase, even as resources are directed to these currently stronger contributors to disease burden.

A variety of estimates of health costs are also available (Table V). Overall, the cost estimates indicate that expenditures are substantial. In the United States, with historically high smoking and attributable burden, the 
Table III

SMOKING-ATTRIBUTABLE MORTALITY (SAM) BY REGIONS AND COUNTRIES OF THE AMERICAS

\begin{tabular}{|c|c|c|c|}
\hline \multirow[t]{2}{*}{ Source } & \multirow[t]{2}{*}{ Location } & \multicolumn{2}{|c|}{$\begin{array}{l}\text { SAM in thousands of deaths } \\
\text { (proportion of total adult mortality) }\end{array}$} \\
\hline & & Male & Female \\
\hline Ezzati and Lopez, $2004^{7}$ & AMR-A & $352(28 \%)$ & $294(21 \%)$ \\
\hline Year of study 2000 & AMR-B & $163(15 \%)$ & $58(6 \%)$ \\
\hline \multirow{8}{*}{ Ages $\geq 30$} & AMR-D & $5 \quad(3 \%)$ & $\mathrm{I}(\mathrm{I} \%)$ \\
\hline & Latin America & 52066 (7.1\%) & 12247 (2.1\%) \\
\hline & Andean Area & $3584 \quad(3.3 \%)$ & $1716(1.8 \%)$ \\
\hline & Colombia & I 784 & $977(2.5 \%)$ \\
\hline & Peru & $184(0.9 \%)$ & NA \\
\hline & Venezuela & I 434 (6.3\%) & $739(3.9 \%)$ \\
\hline & Southern Cone* & $19754(12.4 \%)$ & $2308(1.8 \%)$ \\
\hline & Argentina & 14370 (13.1\%) & I 473 (I.6\%) \\
\hline \multirow{2}{*}{ Surgeon's General report, $1992^{23}$} & Chile & $2549 \quad(8.3 \%)$ & $727(2.9 \%)$ \\
\hline & Brazil & 17945 (7.5\%) & 4 I56 (2.3\%) \\
\hline \multirow{9}{*}{$\begin{array}{l}\text { Year of study } 1985 \\
\text { Ages } \geq 35\end{array}$} & Central America $^{\ddagger}$ & $431 \quad(1.3 \%)$ & $140(0.5 \%)$ \\
\hline & Mexico & $4920 \quad(3.7 \%)$ & 2052 (I.8\%) \\
\hline & Latin Caribbean & $3432(8.6 \%)$ & | 877 (3.6\%) \\
\hline & Cuba & $4517(14.6 \%)$ & | $67 \mid$ (6.9\%) \\
\hline & Caribbean & I 030 (6.2\%) & $218(1.5 \%)$ \\
\hline & North America ${ }^{\S}$ & $214696(19.9 \%)$ & $95562(9.5 \%)$ \\
\hline & Canada & 19147 (21.1\%) & $6631(8.8 \%)$ \\
\hline & USA & $195519(19.8 \%)$ & 88928 (9.6\%) \\
\hline & All regions of Americas & $267792(14.6 \%)$ & 108027 (6.7\%) \\
\hline
\end{tabular}

AMR-A: Canada, Cuba, USA

AMR-B:Antigua and Barbuda,Argentina, Bahamas, Barbados, Belize, Brazil, Chile, Colombia, Costa Rica, Dominica, Dominican Republic, El Salvador, Grenada, Guyana, Honduras, Jamaica, Mexico, Panama, Paraguay, Saint Kitts and Nevis, Saint Lucia, Saint Vincent and the Grenadines, Suriname, Trinidad and Tobago, Uruguay, Venezuela

AMR-D: Bolivia, Ecuador, Guatemala, Haiti, Nicaragua, Peru

* Includes Falkand Islands

$\ddagger$ Excludes Belize

$\S$ Includes Bermuda and St. Pierre and Miquelon

costs approximate $6-8 \%$ of medical expenditures. ${ }^{8}$ These estimates are relatively robust to the estimation method. For Mexico, several estimates have been made based on review of case records at the Instituto Mexicano del Seguro Social (IMSS). At the national level, an estimated $4.3 \%$ of the IMSS budget was expended for disease costs related to smoking. ${ }^{28}$

\section{Conclusions}

Estimation of the burden of disease is now a well established tool for translating scientific findings into policy-relevant information. The major indicators used include morbidity, mortality, and costs. There is a long tradition of estimating the numbers of smoking-caused deaths that dates back to the 1953 paper by Levin. Three approaches have been applied based on the concept of the population-attributable risk: 1) use of the CPS II RR estimates in SAMMEC, developed by the U.S. CDC; 2) use of the lung cancer mortality rate with scaling of the CPS II RR estimates, as proposed by Peto et al.; and 3) the estimates made by for the Global Burden of Disease project, as proposed by Ezzati and Lopez. Cost estimates have been made using the same underlying concept. The uncertainties inherent in these estimates are recognized; in fact, the U.S. CDC is currently reas- 
Table IV

\section{COUNTRY-SPECIFIC ESTIMATES OF SMOKING-ATTRIBUTABLE MORBIDITY AND MORTALITY}

\begin{tabular}{|c|c|c|c|c|}
\hline Source & Location & Total & Male & Female \\
\hline & & \multicolumn{3}{|c|}{ Smoking-attributable DALYs, years } \\
\hline \multirow{3}{*}{$\begin{array}{l}\text { Oliveira et al., } 2008^{30} \\
\text { Year of study } 2000 \\
\text { Ages } \geq 30\end{array}$} & & & & \\
\hline & State of Rio de Janeiro, Brazil & 813052 & $46 \mid 944$ & 351108 \\
\hline & & \multicolumn{3}{|c|}{ Population attributable risk, \% } \\
\hline $\begin{array}{l}\text { Ossip-Klein, et al., } 2008^{31} \\
\text { Year of study } 2003\end{array}$ & Dominican Republic & NA & 36.6 & 24.4 \\
\hline \multirow[t]{2}{*}{$\begin{array}{l}\text { Kuri-Morales et al., } 2002^{32} \\
\text { Year of study } 1998\end{array}$} & Mexico City, Mexico & $45^{\mathrm{a}}$ & NA & NA \\
\hline & & \multicolumn{3}{|c|}{ Smoking-attributable YPLLs, years } \\
\hline $\begin{array}{l}\text { Correa et al., } 2009^{33} \\
\text { Year of study } 2003 \\
\text { Ages } \geq 35\end{array}$ & 16 Brazilian capitals & 419935 & 279990 & 139945 \\
\hline $\begin{array}{l}\text { Rehm et al., } 2007^{34} \\
\text { Year of study } 2002\end{array}$ & Canada & 515607 & 199191 & 316417 \\
\hline $\begin{array}{l}\text { CDC, } 1995^{35} \\
\text { Year of study } 1992\end{array}$ & Mexico & $40168^{\ddagger}$ & $25172^{\ddagger}$ & $14996^{\ddagger}$ \\
\hline $\begin{array}{l}\text { Dietz et al., }\left.199\right|^{36} \\
\text { Year of study } 1983\end{array}$ & Puerto Rico & 19445 & 15120 & 4325 \\
\hline CDC SAMMEC $^{12}$ & & & & \\
\hline $\begin{array}{l}\text { Year of study } 2004 \\
\text { Ages } \geq 35\end{array}$ & United States & 5392787 & 3191883 & 2200904 \\
\hline \multicolumn{5}{|c|}{ Smoking-attributable mortality, number of deaths (proportion of total adult mortality) } \\
\hline $\begin{array}{l}\text { Correa et al., } 2009^{33} \\
\text { Year of study } 2003 \\
\text { Ages } \geq 35\end{array}$ & 16 Brazilian capitals & $24222(13.6 \%)$ & $16896(18.1 \%)$ & $7326(8.7 \%)$ \\
\hline $\begin{array}{l}\text { Baliunas et al., } 2007^{37} \\
\text { Year of study } 2002\end{array}$ & Canada & $37209(16.6 \%)$ & $23766(21 \%)$ & $14443(12.2 \%)$ \\
\hline $\begin{array}{l}\text { Perez et al., } 2009^{38} \\
\text { Years of study } 1995 \text { and } 2007\end{array}$ & Cuba & $\begin{array}{l}\text { II } 951(15 \%) \\
15083(18 \%)\end{array}$ & $\begin{array}{r}806 \mid(19 \%) \\
10443(24 \%)\end{array}$ & $\begin{array}{l}3890(11 \%) \\
4640(12 \%)\end{array}$ \\
\hline $\begin{array}{l}\text { Ossip-Klein et al., } 2008^{31} \\
\text { Year of study } 2003\end{array}$ & Dominican Republic & 2254 & 468 & 785 \\
\hline $\begin{array}{l}\text { Tapia Conyer et al., } 1994^{26} \\
\text { Year of study } 1986 \\
\text { Ages }>20\end{array}$ & Mexico & 17405 & NA & NA \\
\hline $\begin{array}{l}\text { CDC, } 1995^{35} \\
\text { Year of study } 1992\end{array}$ & Mexico & 10253 & 6875 & 3378 \\
\hline $\begin{array}{l}\text { Stevens et al., } 2008^{27} \\
\text { Year of study } 2004\end{array}$ & Mexico & $24336(5.2 \%)$ & $15840(6 \%)$ & $8815(4.3 \%)$ \\
\hline $\begin{array}{l}\text { Dietz et al., }\left.199\right|^{36} \\
\text { Year of study |983 }\end{array}$ & Puerto Rico & $2468(11.5 \%)$ & I 819 (30.9\%) & $649(14.6 \%)$ \\
\hline $\begin{array}{l}\text { CDC, } 2008^{39} \\
\text { Years of study 2000-2004 } \\
\text { Ages } \geq 35\end{array}$ & United States & NA & 269655 & 173940 \\
\hline $\begin{array}{l}\text { Rodu and Cole, } 2007^{40} \\
\text { Years of study } 1987 \text { and } 2002 \\
\text { Ages } \geq 35\end{array}$ & United States & $\begin{array}{l}402000 \\
322000\end{array}$ & $\begin{array}{l}556000 \S \\
329000 \S\end{array}$ & $\begin{array}{l}175000 \$ \\
122000 \$\end{array}$ \\
\hline $\begin{array}{l}\text { CDC SAMMEC } 12 \\
\text { Year of study } 2004 \\
\text { Ages } \geq 35\end{array}$ & United States & 379725 & 22647 I & 153254 \\
\hline
\end{tabular}

SAM=smoking-attributable mortality, PAR=population attributable risk;YPLL=years of potential life lost; DALYs=disability-adjusted life years

* PAR \% for cardiovascular disease

$\ddagger$ YPLL before age 65 years

$\S$ Deaths per 100000 person-years adjusted to the U.S. 2000 standard population 
Table V

COUNTRY-SPECIFIC ESTIMATES OF SMOKING-ATTRIBUTABLE EXPENDITURES (SAE)

\begin{tabular}{|c|c|c|c|}
\hline Source & Location, year of study & Total SAE & Comment \\
\hline Single et al., $1998^{41}$ & Canada, 1992 & \multicolumn{2}{|l|}{$\$ 9.56$ billion CAD ( $1.39 \%$ of GDP) } \\
\hline Rehm et al., $2007^{34}$ & Canada, 2002 & \multicolumn{2}{|l|}{$\$ 17$ billion CAD (total cost per capita: $\$ 54$ I CAD) } \\
\hline Reynales-Shigemasu et al., $2005^{42}$ & Morelos, Mexico, 200I & $\begin{array}{l}\$ 124 \text { million MP }(7.3 \% \text { of annual budget }) \\
A M I^{*}: \$ 80 \text { thousand MP } \\
C O P D^{*}: \$ 73 \text { thousand MP } \\
L C^{*}: \$ 102 \text { thousand MP }\end{array}$ & $\begin{array}{l}{ }^{*} \text { Cost of diagnosis and first } \\
\text { year of treatment }\end{array}$ \\
\hline & $\begin{array}{l}\text { Mexico } \\
2001\end{array}$ & $\begin{array}{l}\text { COPD: } \$ 28.5 \text { thousand USD } \\
\text { CVD: } \$ 2.533 \text { million USD } \\
\text { LC: } \$ 1.49 \text { I million USD } \\
\text { Full course of nicotine gum: } \\
\$ 79.4 \text { thousand USD }\end{array}$ & \\
\hline Arredondo et al., $2002^{43}$ & 2002 & $\begin{array}{l}\text { COPD: } \$ 29.1 \text { thousand USD } \\
\text { CVD: } \$ 2.626 \text { million USD } \\
\text { LC: } \$ 1.569 \text { million USD } \\
\text { Full course of nicotine gum: } \\
\$ 83.7 \text { thousand USD }\end{array}$ & $\begin{array}{l}\text { Exchange rate: } \$ 9.40 \mathrm{MP} \\
\text { per } \$ \text { I USD }\end{array}$ \\
\hline & 2003 & $\begin{array}{l}\text { COPD: } \$ 35.4 \text { thousand USD } \\
\text { CVD: } \$ 2.643 \text { million USD } \\
\text { LC: } \$ 1.683 \text { million USD } \\
\text { Full course of nicotine gum: } \\
\$ 114 \text { thousand USD }\end{array}$ & \\
\hline Reynales-Shigematsu et al., $2006^{28}$ & Mexico, 2004 & $\begin{array}{l}\$ 7.1 \text { billion MP (4.3\% of annual expenditures) } \\
\text { AMI: } \$ 7.1 \text { I billion MP } \\
\text { Cerebrovascular disease: } \$ 3.42 \text { billion MP } \\
\text { COPD: } \$ 1.47 \text { billion MP } \\
\text { LC: } \$ 102 \text { million MP }\end{array}$ & $\begin{array}{l}\text { Random sample of clinical } \\
\text { files }(n=\mid 596) \text {. } \\
\text { In Spanish }\end{array}$ \\
\hline Dietz et al., $|99|^{36}$ & Puerto Rico, 1983 & $\begin{array}{l}\$ 55.9 \text { million USD } \\
\text { Total male: } \$ 38.8 \text { million USD } \\
\text { Total female: } \$ 17.1 \text { million USD }\end{array}$ & \\
\hline$C D C, 2002^{44}$ & United States, 1995-1999 & $\begin{array}{l}\$ 157.7 \text { billion USD } \\
\text { Per smoker }=\$ 3.4 \text { thousand USD }\end{array}$ & \\
\hline CDC, $2008^{39}$ & Untied States, 2000-2004 & $\$ 193$ billion USD & \\
\hline CDC SAMMEC ${ }^{12}$ & United States, 2004 & $\$ 96$ billion USD ${ }^{+}$ & $\begin{array}{l}\text { +SAE based on Centers } \\
\text { for Medicaid \& Medicare } \\
\text { Services, } 1999 .\end{array}$ \\
\hline
\end{tabular}

CAD = Canadian Dollars; $M P=$ Mexican Pesos $;$ USD = United States Dollars; $C O P D=$ chronic obstructive pulmonary disease CVD = cardiovascular disease; $\mathrm{LC}=$ lung cancer; $\mathrm{AMI}=$ acute myocardial infarction

sessing its approach in an effort to update the RR estimates and to more clearly address uncertainty.

Estimation of attributable risks and costs has proved valuable in the United States for informing the public and policy makers as to the magnitude of the disease burden caused by cigarette smoking. The repeated designation of smoking as the cause of the largest number of avoidable premature deaths has been effective in motivating action. The cost estimates figured prominently in litigation by the States, and are also useful for motivating health care systems to seriously address tobacco use among enrollees.
There is the potential for improving estimates of the burden of smoking across the Americas. A number of countries, including Mexico and Brazil, are carrying out the new Global Adult Tobacco Survey (GATS), which will provide national data on prevalence. National cohort studies for estimation of RRs are lacking, however, and are needed given the limited applicability of the CPS II estimates across the Americas.

The available data indicate the potential for health benefits from tobacco control across the Americas. The magnitudes of the benefits vary widely from countries with only a few percent of deaths attributable to smok- 
ing to the far higher U.S. estimates. Those countries that have ratified the Framework Convention on Tobacco Control, including Mexico, have made a commitment to a national program for tobacco control. These efforts will need to be sustained for decades. ${ }^{29}$

\section{Declaration of conflicts of interest}

I declare that I have no conflicts of interest.

\section{References}

I. Levin ML. The occurrence of lung cancer in man. Acta Un Intern Cancer. |953;9:53|-41.

2. Levin ML, Goldstein H, Gerhardt PR. Cancer and tobacco smoking. A preliminary report. Journal of the American Medical Association. 1950;143:336-8.

3. Doll R, Hill AB. Smoking and carcinoma of the lung. British Medical Journal. 1950;2(468I):739-48.

4. Wynder EL, Graham EA. Tobacco smoking as a possible etiologic factor in bronchiogenic carcinoma. A study of six hundred and eightyfour proved cases. Journal of the American Medical Association. 1950;143(4):329-36.

5. Miura M, Daynard RA, Samet JM. The role of litigation in tobacco control. Salud Publica Mex. 2006;48 (Supplement I):SI II-S36. 6. U.S. Department of Health and Human Services. The health consequences of smoking.A report of the Surgeon General.Atlanta, GA: U.S. Department of Health and Human Services, Centers for Disease Control and Prevention, National Center for Chronic Disease Prevention and Health Promotion, Office on Smoking and Health; 2004.

7. Ezzati M, Lopez AD. Regional, disease specific patterns of smokingattributable mortality in 2000. Tob Control. 2004;I3(4):388-95. PMCID: 1747946.

8. Warner KE, Hodgson TA, Carroll CE. Medical costs of smoking in the United States: estimates, their validity, and their implications. Tob Control. 1999:8(3):290-300.

9. Benichou J.A review of adjusted estimators of attributable risk. Stat Methods Med Res. 2001;10(3):195-216.

10. Greenland S, Robins JM. Conceptual problems in the definition and interpretation of attributable fractions. Am J Epidemiol. 1988;128(6): I 185-97.

II. Rothman KJ. Causes. American Journal of Epidemiology. 1976; 104(6):587-92.

12. Centers for Disease Control and Prevention. Smoking-attributable mortality, morbidity and economic costs (SAMMEC).Atlanta: U.S. Department of Health and Human Services; 2010 [updated 2010; cited March 8]; Available from: http://apps.nccd.cdc.gov/sammec/. 13. Thun MJ, Day-Lally C, Myers DG, Calle EE, Flanders WD, Zhu BP, et al. Trends in tobacco smoking and mortality from cigarette use in Cancer Prevention Studies I (1959-1965) and II (1982-1988). In: Burns DM, Garfinkel L, Samet JM, editors. Changes in Cigarette Related Disease Risks and Their Implication for Prevention and Control: Monograph 8. Bethesda, Maryland: U.S. Government Printing Office; 1997:305-82.

14. Peto R, Lopez AD, Boreham J,Thun M, Heath C, Jr. Mortality from tobacco in developed countries: indirect estimation from national vital statistics. Lancet. 1992;339(8804): 1268-78.

15. Peto R, Lopez AD, Boreham J, Thun M. Mortality from smoking in developed countries 1950-2000 (2nd edition: updated June 2006). 2006 [updated 2006; cited 2010 March 8]; Available from: http://www.ctsu.ox.ac. uk/ tobaccol.
16. Murray CJ. Quantifying the burden of disease: the technical basis for disability-adjusted life years. Bull World Health Organ. 1994;72(3):429-445. PMCID: 2486718

17. World Health Organization. Quantifying the Burden of Disease from mortality and morbidity. Geneva:World Health Organization; 2010 [updated 2010; cited March 8]; Available from: http://www.who.int/ healthinfo/global_burden_disease/metrics_daly/en/.

18. Barendregt JJ, Bonneux L, van der Maas PJ. The health care costs of smoking. New England Journal of Medicine. 1997;337(15):1052-7.

19. Johnson E, Dominici F, Griswold M, Zeger S. Disease cases and their medical costs attributable to smoking: an analysis of the national medical expenditure survey. Journal of Econometrics. 2003; I 12(I):135-5I.

20. Miller LS, Zhang X, Rice DP, Max W. State estimates of total medical expenditures attributable to cigarette smoking, 1993. Public Health Rep. 1998; | I3(5):447-58. PMCID: I 3084I6.

21. MillerVP, Ernst C, Collin F. Smoking-attributable medical care costs in the USA. Social Science \& Medicine. 1999;48:375-91.

22. Zeger SL,Wyant T, Miller LS, Samet JM, Gastwirth J. Statistical testimony on damages in Minnesota v. Tobacco Industry. Statistical science in the courtroom. New York: Springer-Verlag; 2000.

23. U.S. Department of Health and Human Services. A report of the Surgeon General in collaboration with the Pan American Health Organization: Smoking and Health in the Americas. Atlanta GA:U.S. DHHS, Public Health Service, Centers for Disease Control, National Center for Chronic Disease Prevention and Health Promotion, Office on Smoking and Health; DHHS Publication No. (CDC) 92-8419; 1992. 24. Ezzati M, Lopez AD. Estimates of global mortality attributable to smoking in 2000. Lancet. 2003;362(9387):847-52.

25. Yusuf S, Hawken S, Ounpuu S, Dans T,Avezum A, Lanas F, et al. Effect of potentially modifiable risk factors associated with myocardial infarction in 52 countries (the INTERHEART study): case-control study. Lancet. 2004;364(9438):937-52.

26. Tapia-Conyer R, Olaiz G, Cravioto P. [Mortality and possible lost years of life due to tobacco consumption in Mexico]. Gac Med Mex. 1994;।30(6):425-3|.

27. Stevens G, Dias RH,Thomas KJ, Rivera JA, Carvalho N, Barquera S, et al. Characterizing the epidemiological transition in Mexico: national and subnational burden of diseases, injuries, and risk factors. PLoS Med. 2008;5(6):el25. PMCID: 2429945.

28. Reynales-Shigematsu LM, Rodriguez-Bolanos Rde L, Jimenez JA, Juarez-Marquez SA, Castro-Rios A, Hernandez-Avila M. [Health care costs attributable to tobacco consumption on a national level in the Mexican Social Security Institute]. Salud Publica Mex. 2006;48 Suppl I:S48-64. 29. Samet JM,Wipfli HL. Globe still in grip of addiction. Nature. 2010;463(7284):1020-I.

30. Oliveira AF,Valente JG, Leite IC. The disease burden attributable to smoking in the state of Rio de Janeiro, Brazil in 2000. Clinics (Sao Paulo). 2008;63(2):215-22. PMCID: 26642I3.

31. Ossip-Klein DJ, Fisher S, Diaz S, Quinones Z, Sierra E, Dozier A, et al. Tobacco use in six economically disadvantaged communities in the Dominican Republic. Nicotine Tob Res. 2008; I0(5):85I-60. PMCID: 2730378. 32. Kuri-Morales P,Alegre-Diaz J, Mata-Miranda Mdel P, Hernandez-Avila M. [Mortality attributable to tobacco use in Mexico]. Salud Publica Mex. 2002;44 Suppl I:S29-33.

33. Correa PC, Barreto SM, Passos VM. Smoking-attributable mortality and years of potential life lost in 16 Brazilian capitals, 2003: a prevalence-based study. BMC Public Health. 2009;9:206. PMCID: 27I 1948.

34. Rehm J, Gnam W, Popova S, Baliunas D, Brochu S, Fischer B, et al. The costs of alcohol, illegal drugs, and tobacco in Canada, 2002.J Stud Alcohol Drugs. 2007;68(6):886-95

35. Smoking-attributable mortality--Mexico, 1992. MMWR Morb Mortal Wkly Rep. 1995;44(19):372-3, 9-81. 
36. Dietz VJ, Novotny TE, Rigau-Perez JG, Schultz JM. Smoking-attributable mortality, years of potential life lost, and direct health care costs for Puerto Rico, 1983. Bull Pan Am Health Organ. 1991;25(I):77-86.

37. Baliunas D, Patra J, Rehm J, Popova S, Kaiserman M, Taylor B. Smokingattributable mortality and expected years of life lost in Canada 2002: conclusions for prevention and policy. Chronic Dis Can. 2007;27(4):154-62. 38. Perez PV,Traveieso DH, Roche RGG, Gorbea MB, Perez TR, Fernadez SJV. Smoking-attributable mortality in Cuba. MEDICC Review. 2009; I I(3):43-7.

39. Centers for Disease Control and Prevention. Smoking-attributable mortality, years of potential life lost, and productivity losses--United States, 2000-2004. MMWR Morb Mortal Wkly Rep. 2008;57(45):1226-8. 40. Rodu B, Cole P. Declining mortality from smoking in the United States. Nicotine Tob Res. 2007;9(7):78I-4
4I. Single E, Robson L, Xie X, Rehm J.The economic costs of alcohol, tobacco and illicit drugs in Canada, 1992. Addiction. 1998;93(7):991- 1006. 42. Reynales-Shigematsu LM, Juarez-Marquez SA, Valdes-Salgado R. [Costs of medical care attributable to tobacco consumption at the Mexican Institute of Social Security (IMSS), Morelos]. Salud Publica Mex. 2005;47(6):45I-7.

43. Arredondo A, Parada I, Carrillo C. Financial consequences of changes in health care demands related to tobacco consumption in Mexico: information for policy makers. Health Policy. 2002;6I(I):43-55.

44. Centers for Disease Control and Prevention. Annual smokingattributable mortality, years of potential life lost, and economic costs--United States, 1995-1999. MMWR Morb Mortal Wkly Rep. 2002;5I(I4):300-3. 